\title{
Controls on Floc Size in the Sea
}

Paul S. Hill

Dept. of Oceanography • Dalhousie University • Halifax, Nova Scotia • B3H 4J1 • CANADA

\section{Introduction}

If you scoop a glass of water from the sea and look beyond the wonders of biology therein, you see particles (Fig.1). Detritus of the many biogeochemical processes at work in the ocean, particles influence fundamentally the transport of mass and transmission of

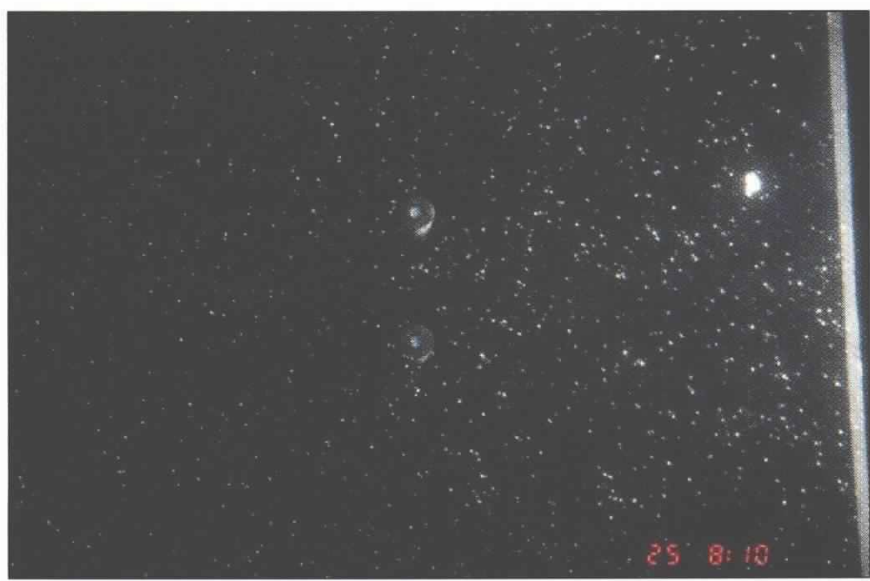

Figure 1 A photograph of particles in suspension $130 \mathrm{~m}$ below the surface of Disenchantment Bay, a fjord in Southeast Alaska. The bright line at the right is the light source. For scale, the centers of the two calibration objects in the middle of the image are $5 \mathrm{~cm}$ apart. The white specs are flocs that are approximately $1 \mathrm{~mm}$ in diameter and account for about 3/4 of the mass in suspension.

energy through the water column. Particle sinking is a major pathway for transfer of carbon and nutrients from surface waters to the deep sea, thereby playing a crucial role in global climate (Suess, 1980; Asper et al., 1992). Particles offer abundant surface area for adsorption of numerous hydrophobic anthropogenic contaminants, so the fate of pollutants in the sea is linked inextricably with the fate of particles (Milligan and Loring, 1997; Gustafsson et al., 1998). Particles scatter light, so they affect the growing conditions for phytoplankton at the

\section{... understanding of particles is a keystone for overall understanding \\ of the seas.}

The myriad roles played by particles in the sea all are affected by particle size distribution. One of the great gifts of nature to curious scientists is the fact that surface-area-to-volume ratio decreases with increasing particle size. This simple fact makes large particles sink faster than smaller ones of the same composition; it makes small particles more adsorptive per unit of mass; and it makes larger particles scatter less light per unit of mass than smaller particles. The fundamental importance of particle size distribution has bred continuing efforts to quantify it in the sea.

One of the most important lessons learned from studies of marine particle size distributions is that often the majority of particles in the sea do not exist as single grains, but rather are parts of large aggregates of particles, variously called flocs, aggregates, or, more poetically, marine snow (Eisma, 1986; Fowler and Knauer, 1986). Instruments that estimate particle size without collecting or otherwise disturbing a suspension show that mass typically resides in a relatively uniform population of flocs with diameters of several hundred micrometers or more (Figs. 1 and 2). If that same suspension is collected and purposely reduced to its component particles, a poorly sorted population of particles orders of magnitude smaller than the parent flocs emerges (Kranck and Milligan, 1992). By using estimated size-density relationships for flocs, the mass concentration in flocs can be estimated, and it often accounts for well over half of the total mass in a suspension. Thus, developing knowledge of floc properties lies on the road to understanding marine particle dynamics.

The tendency of particles to flocculate complicates considerably the task of developing predictive knowledge of particle dynamics. In the simplest models that incorporate flocculation, particles can exist as single grains or flocs (Kranck and Milligan, 1991; Lavelle, 1993). Predicting their fate requires expressions for singlegrain and floc settling velocities, as base of the oceans' food webs (Campbell and Spinrad, 1987; Bricaud et al., 1995). Concealed within particles that come to rest on the seafloor is a record of environmental change that paleoceanographers and geologists are devoting great effort to unraveling (Kranck, 1984; McCave et al., 1995). The list of particle roles in the sea goes on, but perhaps this one is sufficient to make the point that understanding of particles is a keystone for overall understanding of the seas. well as terms for exchange rates, via aggregation and disaggregation, between single grain and floc populations. Settling velocities of single grains are well understood, but settling velocities of flocs, aggregation rate, and disaggregation rate are not. Therefore, these three topics have garnered much attention in recent research into marine particle dynamics.

Three hypotheses regarding floc settling velocity and breakup make implementation of even simple models daunting (Dyer, 1989). First, floc settling velocity pre- 


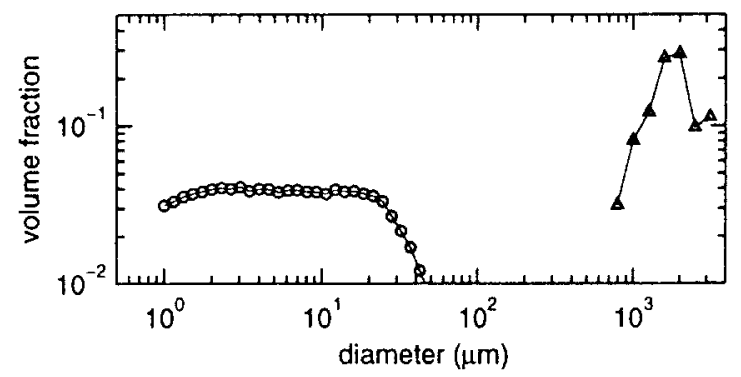

Figure 2 In situ floc size distribution (triangles) and disaggregated inorganic size distribution (circles) from the image in Fig. 1. The floc size distribution derives from image analysis of the digitized photograph, and the disaggregated size distribution was generated using a Coulter Multisizer Ile to analyze the contents of a Niskin bottle collected at the same depth as the photograph. Although no organic particles are represented in the disaggregated size distribution, the environment at the head of the fiord where the'se samples were taken was dominated by inorganic silt and clay discharged at the tidewater terminus of Hubbard glacier. Component inorganic grains are poorly sorted and orders of magnitude smaller than the wellsorted flocs in which they are packaged in situ.

sumably depends on suspended particle concentration. Second, floc settling velocity is limited by turbulenceinduced forces, and third, physical disaggregation by turbulence is the dominant mechanism for liberating mass from flocs. If all of these hypotheses are true, a predictive understanding of particle dynamics requires detailed knowledge of the spatial and temporal distribution of particle concentration and turbulence in a suspension. The goal
Alternative hypotheses that can explain

direct floc observations

as well as settling-column data are needed. niques have been used to convert clearance rate to a median effective settling velocity, $w 50$, for the suspension. These settling columns consistently produce values of $w 50$ that increase with increasing concentration (Fig.3).

Studies using direct observations of flocs to test explicitly the hypothesis that floc size and settling velocity depend on concentration have failed to find evidence supporting it. ten Brinke (1994) made direct videographic observations of floc settling velocity in the field, and he found no dependence on concentration. Milligan and Hill (1998) photographically examined maximal floc size as a function of concentration in a laboratory flocculator and also saw no relation (Fig.4). The failure of direct observations to support this hypothesis seriously compromises it. The settling-column data invoked to support it are indirect and open to other interpretations. Alternative hypotheses that can explain direct floc observations as well as settling-column data are needed.

\section{Floc Settling Velocity and Turbulence}

Another common assumption in fine sediment research is that under all conditions maximal floc settling velocity is controlled by turbulence (Jackson, 1995; Hill, 1996; Ruiz and Izquierdo, 1997). This assumption rests on the third common assumption in floc studies, which states that turbulence-induced stresses dominate particle disaggregation. These assumptions derive from many observations of reductions in floc size of this paper is to provoke discussion by outlining the conceptual basis for these hypotheses; evaluating data used to support them; and discussing recent observations that cast doubt on their validity. These observations are particularly exciting because they suggest that under a wide range of conditions, a much simpler model of floc dynamics may suffice.

\section{Floc Settling Velocity and Concentration}

A common assumption in fine-sediment research holds that floc settling velocity increases as sediment concentration grows (Dyer, 1989). A compelling argument underlies this assumption. It maintains that maximal floc size and settling velocity reflect a dynamical balance between aggregation and disaggregation rates. Aggregation rate, which scales with the square of concentration, increases faster with increasing concentration than does disaggregation rate, which only scales linearly with concentration. As a result, increases in concentration push the size for which aggregation and disaggregation rates balance to larger diameters.

Data from field-deployed settling columns have long been used to support the assumption that floc settling velocity depends on concentration (Burt, 1986; Dyer et al., 1996) (Fig. 3). In general, these devices operate by enclosing a volume of suspension that is monitored to determine clearance rate of sediment mass. Several tech- associated with vigorous turbulence (Kranck and Milligan, 1992; Luettich et al., 1993; Eisma et al., 1996).

No explicit tests of the hypothesis that floc settling velocity depends on turbulence have been conducted in the laboratory or the field. Yet numerous in situ direct observations of sinking flocs from diverse environments yield similar results, casting doubt on the notion that

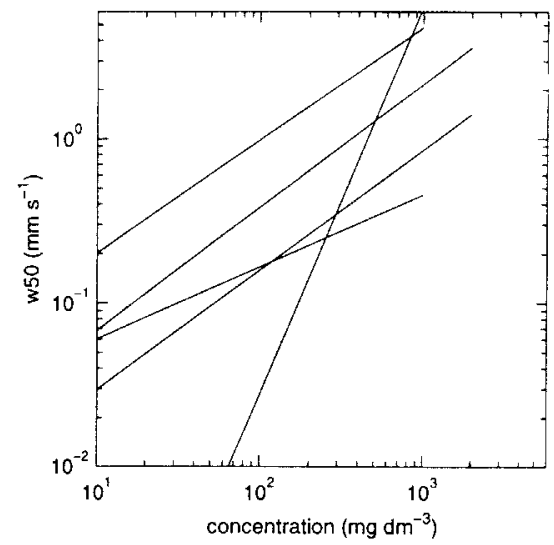

Figure 3 Best fits of median effective settling velocity (w50) to concentration from Dyer et al. (1996). In an inter-comparison of instruments for measuring settling velocity, various in situ settling columns all produced increases in clearance rate with increasing concentration. These results were interpreted as indicative of concentration dependente of floc settling velocity. An alternative explanation is that concentration dependence of clearance rate reflects the action of floc breakup and reformation in the collumns. See text for details. 


\begin{tabular}{|c|c|c|}
\hline $\begin{array}{l}\text { Settling velocity } \\
\qquad \mathrm{mm} \mathrm{s}\end{array}$ & Environment & Source \\
\hline 1.3 & upwelling region & $\begin{array}{l}\text { Alldredge and } \\
\text { Gotschalk (1989) }\end{array}$ \\
\hline $0.56-2.82$ & estuary & $\begin{array}{c}\text { van Leussen and } \\
\text { Cornelisse (1993) }\end{array}$ \\
\hline 1.54 & estuary & ten Brinke (1994) \\
\hline $1-3$ & estuary & Dyer et al. (1996) \\
\hline 2.2 & fjord & Hill et al. (1998) \\
\hline $1-3.8$ & continental shelf & $\begin{array}{l}\text { Sternberg et al. } \\
\text { (in press) }\end{array}$ \\
\hline
\end{tabular}

turbulence plays a key role in determining settling velocity. Such observations were made in 1995 by deploying an in situ camera in Tarr Inlet, Glacier Bay, Alaska (Hill et al., 1998). The camera took series of photographs in which flocs were sized and tracked from image to image. From size and settling velocity, effective density was calculated. The data gathered in Tarr Inlet bear close resemblance to data gathered elsewhere with different instruments. First, floc effective density decreases with increasing floc size (Fennessy et al., 1994; ten Brinke, 1994, Syvitski et al., 1995; Dyer et al., 1996) (Fig. 5). This behavior stems from incorporation of progressively more pore space into flocs as they grow. The correlation of porosity and size leads to dependence of settling velocity on diameter that is weaker than the

Although it is clear that turbulence can disrupt flocs, the turbulent-kinetic-energy dissipation rates required to do so apparently exceed those found throughout much of the ocean.

The assumption that turbulence destroys flocs underlies most studies of marine particle dynamics (Jackson, 1995; Hill, 1996; Ruiz and Izquierdo, 1997). Floc diameters generally fall below the dimension of the smallest eddies in a turbulent suspension. At these small scales, turbulence induces linear shear that presumably rends flocs. The magnitude of the shear is determined by the turbulent-kinetic-energy dissipation rate, $\varepsilon$. Numerous theoretical studies in the fields of material processing and wastewater treatment have investigated turbulence-mediated breakup of flocs. In general such theories predict that maximal floc size scales as $\varepsilon^{t}$ where the exponent $b$ varies between $1 / 4$ and 1, depending on breakup mechanism (Burt, 1986; Alldredge et al., 1990). Laboratory studies generally support these theories, so oceanographers have applied similar models of disaggregation to marine particles.

Ample evidence exists suggesting that turbulence can destroy flocs. Observations of flocs in the field show that smaller flocs occur in higher energy environments (Kranck and Milligan, 1992; Luettich et al., 1993; Berhane et al., 1997). Vertical profiles of floc size in an estuary show that smaller flocs occur near the seabed, where turbulent-kineticenergy dissipation rates are higher (Eisma et al., 1996), and laboratory studies also show that floc size decreases as $\varepsilon$ increases (Milligan and dependence predicted by Stokes Law for particles of constant density. Second, and more importantly, the mean floc settling velocity in Tarr Inlet is approximately $2 \mathrm{~mm} \mathrm{~s}^{-1}$, which is close to settling velocity estimated by direct observations in a variety of other environments (Table 1).

Indirect methods of estimating in situ settling velocity also yield values in the range of $\mathrm{mm} \mathrm{s}^{-1}$, or in perhaps more familiar units, $100 \mathrm{~m} \mathrm{day}^{-1}$, (Table 2). Sediment traps deployed around the globe in a variety of environments reveal lags between sedimentation events at different depths that are best explained by repackaging of particles into flocs sinking at $100 \mathrm{~m} \mathrm{day}^{-1}$. Simulations of vertical distribution of fine suspended sediment in bottom boundary layers often require settling velocities in the range of $1 \mathrm{~mm} \mathrm{~s}^{-1}$ in order to fit data.

Although estimates of turbulent energy do not accompany the numerous observations and extrapolations of floc settling velocities of order $1 \mathrm{~mm} \mathrm{~s}^{-1}$, the energy levels in the variety of environments from which the values come clearly differ. Environments range from quiescent ocean interior to a continental shelf stirred by waves and tides to the macrotidal Bay of Fundy (Tables 1 and 2). If turbulence controls floc settling velocity in these diverse settings, measured fall rates should differ. The fact that they do not warrants a search for alternative explanations.

Hill, 1998). Recent observations, however, challenge the idea that turbulence dominates floc breakup in the sea.

Although it is clear that turbulence can disrupt flocs, the turbulent-kinetic-energy dissipation rates required to do so apparently exceed those found throughout much of the ocean. In a laboratory study, Alldredge et al. (1990) introduced five different types of flocs into an oscillating grid turbulence tank. Maximal $\varepsilon$ in the tank was greater than $10^{-4} \mathrm{~W} \mathrm{~kg}^{-1}$, which is large relative to typical $\varepsilon$ in the ocean (Alldredge et al., 1990). It was surprising, therefore, that 3 of 5 floc types experienced no disruption in the tank. Only fragile diatom flocs suffered any breakage, and many of these remained intact. Recent in situ observations of floc size and turbulent shear in a continental-shelf bottom boundary layer support the finding that floc breakage occurs only at relatively high turbulence intensity (Hill et al., submitted).

\begin{tabular}{|cll|}
\hline \multicolumn{3}{|c|}{ Table 2: Inferred settling velocities } \\
\hline $\begin{array}{c}\text { Settling velocity } \\
\mathrm{mm} \mathrm{s}^{-1}\end{array}$ & \multicolumn{1}{|c|}{ Environment } & Source \\
\hline$>0.7$ & upwelling region & Honjo (1982) \\
$1.2-1.7$ & open ocean & Billet et al. (1983) \\
2.1 & macrotidal estuary & Amos and Mosher \\
& & $(1985)$ \\
$\approx 1.2$ & open ocean & Deuser (1986) \\
$>1.2$ & open ocean & Asper et al. (1992 \\
\hline
\end{tabular}




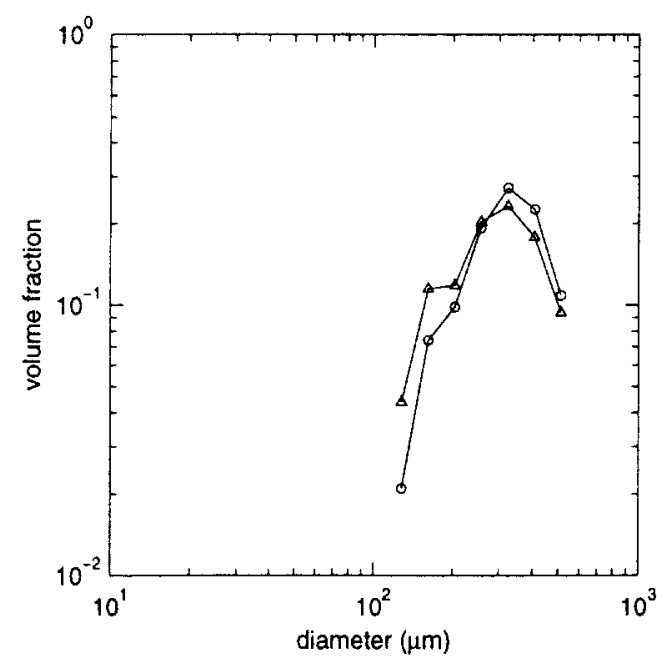

Figure 4 In situ floc size distributions at two concentrations in a laboratory flocculator. The size distribution of flocs of glacimarine clay at a concentration $50 \mathrm{mg} \mathrm{dm}^{-3}$ (circles) does not differ significantly from the size distribution at $250 \mathrm{mg} \mathrm{dm}$ (triangles). These observations, redrawn from Milligan and Hill (1998), support other data that show that floc size and settling velocity do not depend on sediment concentration.

Adding to doubt concerning the central role of turbulence in destroying flocs are observations that indicate that the dependence of maximal floc size on $\varepsilon$ generally is not as strong as predicted. Three floc types in the Alldredge study showed no dependence on $\varepsilon$ over the large range in the tank. For another floc type in the Alldredge study, maximal floc size scaled as $\varepsilon^{-0.11}$, whereas the weakest predicted dependence goes as $\varepsilon^{-025}$. Only one floc type yielded a power-law dependence of maximal floc size on $\varepsilon$ that was not significantly different from theory. Recent in situ observations similarly show much-weaker-than-predicted dependence of maximal floc size on parameters related to $\varepsilon$ (Hill et al., submitted). These disagreements between theory and observations once again suggest our current understanding of floc dynamics needs refinement.

\section{Alternative Hypotheses}

Three hypotheses that are central to understanding floc dynamics fail to explain observations. Alternative hypotheses have been developed that do accommodate recent data. The new view of floc dynamics embodied by these alternatives is considerably simpler than the conventional view.

The first set of observations that clashes with conventional wisdom is the lack of correlation between floc settling velocity and concentration. An alternative explanation for the observed dependence of clearance rate on concentration in settling columns is that floc breakup and reformation produce observed results (Milligan, 1995; Milligan and Hill, 1998). According to this hypothesis, intense turbulence caused by sampling destroys larger flocs. Once enclosed in a relatively quiescent column, floc fragments recombine into large flocs and sink out at a floc settling velocity that does not depend on concentration. The time required to complete this two-step removal pathway decreases as concentration grows because the time required for formation of flocs scales inversely with concentration (Gonzalez and Hill, in press), not because of any concentration dependence of floc settling velocity. Thus, supposed concentration-dependence of settling velocity is a methodological artefact, and knowledge of concentration is not necessary to model floc sinking.

The relative uniformity of floc settling velocity, the observation that flocs tend to break only at high values of $\varepsilon$, and the weaker-than-predicted dependence of maximal floc size on $\varepsilon$ all challenge the view that turbulence limits floc size and settling velocity under all conditions is the sea. Alldredge et al. (1990) proposed microbial degradation, bacterial solubilization, and animal grazing as other mechanisms for limiting floc size in the sea. It is difficult, however, to reconcile these mechanisms with the observed uniformity of floc settling velocities. Settling velocities of order $1 \mathrm{~mm} \mathrm{~s}^{-1}$ have been observed for diverse floc types ranging from diatom-rich marine snow to predominantly inorganic mineral flocs (Alldredge and Gorschalk, 1989; Hill et al., 1998) (Tables 1 and 2). The chemical and biological processes going on within these flocs likely differ and would not be expected to limit flocs to the same general settling velocity.

An alternative hypothesis for control of floc size is that forces imposed on flocs during sinking limit their size (Hill et al., 1998). Sinking obviously induces relative particle-fluid motion, and such motion exerts stresses on a particle. Although sinking-induced stresses are not large, scale analysis shows that at the relatively low values of $\varepsilon$ in the ocean, they often exceed turbulence-induced stresses.

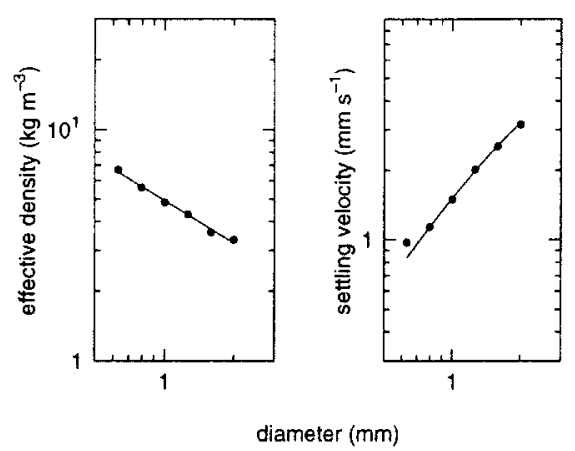

Figure 5 In situ, bin-averaged floc effective density and settling velocity near the seabed of Tarr Inlet, Glacier Bay, Alaska, redrawn from Hill et al. (1998). Floc effectize density decreases as diameter raised to the power -0.61 , so settling velocity increases approximately as diameter raised to the 1.39 . These relationships arise because flocs incorporate progressizely more pore space into their structure as they grow. Mean floc settling velocity for these data is about $2 \mathrm{~mm} \mathrm{~s}^{-1}$, a number consistent with floc settling velocities observed in a variety of environments (Tables 1 and 2). The uniformity of floc settling velocities across environments suggests that, under a wide range of energy, turbulence likely does not limit floc settling velocity. 
The control of floc size by sinking- and turbulenceinduced stresses has received rigorous theoretical treatment by P. M. Adler. His models (Adler and Mills, 1979; Adler, 1979) produced two particularly interesting results. First, he found that below some critical shear, whose value depended on particle strength, shear ceased to limit aggregate size. Second, he determined that stresses induced by sinking always limit floc size. Thus, according to Adler's models, below some critical value, floc size ceases to vary with shear. Above that value, floc size decreases as shear grows. These predictions are more consistent with observations than are the predictions of models that assume that turbulence alone limits floc size. Under this paradigm, modelling particle dynamics becomes much easier under a wide range of conditions. As long as $\varepsilon$ falls below some critical, apparently high, value, floc size and settling velocity do not depend on temporally and spatially varying turbulence levels.

\section{Conclusions}

The advent of technologies for observing flocs directly has shaken the foundations of understanding of floc dynamics in the sea. Indirect observations from settling columns and theory and observations refined for vigorously agitated suspensions support the long-held ideas that factors external to flocs, namely sediment concentration and turbulence, exert strong control over floc properties. At this time, direct observations argue for a simpler view of flocs, specifically that over a wide range of concentration and turbulence intensities, external factors do not influence floc properties. As more and better in situ observations become available, it will become clear under what conditions the simpler view should prevail.

Acknowledgments: I wish to thank Tim Milligan for the almost daily conversations we have on topics like the ones in this paper. I am grateful to Joe Kravitz and James Syvitski for encouraging and supporting extension of my research to the field. This work was funded primarily by the U. S. Office of Naval Research Coastal Mixing and Optics Program.

\section{References}

Adler, P. M., 1979: A study of disaggregation effects in sedimentation. AlChE Journal, 25(3), 487-493.

Adler, P.M. and P.M. Mills, 1979: Motion and rupture of a porous sphere in a linear flow field. Journal of Rheology, 23(1), 25-37.

Alldredge, A.L. and C.C. Gotschalk, 1989: Direct observations of the mass flocculation of diatom blooms: characteristics, settling velocities and formation of diatom aggregates. Deep-Sea Research, 36(2), 159-171.

Alldredge, A.L., T.C. Granata, C.G. Gotschalk, and T.D. Dickey, 1990: The physical strength of marine snow and its implications for particle disaggregation in the ocean. Limnology and Oceanography, 35(7), 1415-1428. Amos, C.L. and D.C. Mosher, 1985: Erosion and deposition of fine-grained sediments from the Bay of Fundy. Sedimentology, 32, 815-832.

Asper, V.L., W.G. Deuser, G.A. Knauer and S.E. Lohrenz, 1992: Rapid coupling of sinking particle fluxes between surface and deep ocean waters. Nature, 357, 670-672.

Berhane, I., R.W. Sternberg, G.C. Kineke, T.G. Milligan and K. Kranck, 1997: The variability of suspended aggregates on the Amazon continental shelf. Continental Shelf Research, 17(3), 267-286.

Billet, D.S.M., R.S. Lampitt, A.L. Rice, R.F.C. Mantoura, 1993: Seasonal sedimentation of phytoplankton to the deep-sea benthos. Nature, 302, 520-522.

Bricaud, A., C.R. Roesler, and J.R.V. Zaneveld, 1995: In situ methods for measuring the inherent optical properties of ocean waters. Limnology and Oceanography, 40(2), 393-410.

Burt, T.N., 1986: Field settling velocities of estuary muds. In Estuarine Cohesive Sediment Dynamics, A.J. Mehta. ed. Springer-Verlag, 126-150.

Campell, D.E. and R.W. Spinrad, 1987: The relationship between light attenuation and particle characteristics in a turbid estuary. Estuarine Coastal and Shelf Science, 25, 53-65.

Deuser, W.G., 1986: Seasonal and interannual variations in deep-water particle fluxes in the Sargasso Sea and their relation to surface hydrography. Deep-Sea Research, 33(2), 225-246.

Dyer, K.R., 1989: Sediment processes in estuaries: future research requirements. Journal of Geophysical Research, 94(C10), 14,327-14,399.

Dyer, K.R., J. Cornelisse, M.P. Dearnaley, M.J. Fennessy, S.E. Jones, J. Kappenberg, I.N. McCave, M. Pejrup, W. Puls, W. Van Leussen, and K. Wolfstein, 1996:

A comparison of in situ techniques for estuarine floc settling velocity measurements. Journal of $S^{\prime} a$ Research, 36-(1-2), 15-29.

Eisma, D., 1986: Flocculation and de-flocculation of suspended matter in estuaries. Netherlands Joumal of Sea Research, 20(2/3), 183-199.

Eisma, D., A.J. Bale, M.P. Dearnaley, M.J. Fennessy, W. Van Leussen, M.A. Maldiney, A. Pfeiffer and J.T. Wells, 1996: Intercomparison of in situ suspended matter (floc) size measurements. Joumal of Sia Research, 36(1-2), 3-14.

Fennessy, M.J., K.R. Dyer, and D.A. Huntley, 1994: INSSEV: An instrument to measure the size and settling velocity of flocs in situ. Marine Geology, 117, 107-117.

Fowler, S.W. and G.A. Knauer, 1986: Role of large particles in the transport of elements and organic compounds through the oceanic water column. Progress in Oceanography, 16, 147-194.

Gonzalez, E.A. and P.S. Hill, in press: A method for estimating the flocculation time of monodispersed sediment suspensions. Deep-Sea Research I. 
Gustafsson, O., K.O. Buesseler, W.R. Geyer, S.B. Moran, and P.M. Gschwend, 1998: An assessment of the relative importance of horizontal and vertical transport of particle-reactive chemicals in the coastal ocean. Continental Shelf Research, 18, 805-829.

Hill, P.S., 1996: Sectional and discrete representations of floc breakage in agitated supensions. Deep-Sea Research I, 43(5), 679-702.

Hill, P.S., J.P. Syvitski, E.A. Cowan, and R.D. Powell, 1998. In situ observations of floc settling velocities in Glacier Bay, Alaska. Marine Geology, 145, 85-94.

Hill, P.S., G. Voulgaris, and J.H. Trowbridge, submitted: Controls on floc size in a continental shelf bottom boundary layer. Continental Shelf Research.

Honjo, S., 1982: Seasonality and interaction of biogenic and lithogenic particulate flux at the Panama Basin, Science, 218, 883-884.

Jackson, G.A., 1995: Comparing observed changes in particle size spectra with those predicted using coagulation theory. Deep-Sea Research II, 42(1), 159-184.

Kranck, K., 1984: Grain-size characteristics of turbidities. In: Fine-grained sediments: deep water processes and facies, D.A.V. Stow and D.J.W. Piper (eds), Blackwell Scientific Publications, Oxford, 83-92.

Kranck, K. and T.G. Milligan, 1991: Grain size in oceanography. In: Principles, methods, and application of particle size analysis, J.P.M. Syvitski (ed), Cambridge University Press, 332-345.

Kranck, K. and T.G. Milligan, 1992: Characteristics of suspended particles at an 11-hour anchor station in San Francisco Bay, California. Journal of Geophysical Research, 97(C7), 11,373-11,382.

Lavelle, J.W., 1993: A model for estuarine sedimentation involving marine snow. In: Nearshore and Estuarine Cohesive Sediment Transport, Coastal and Estuarine Studies Series, 7. 42, A.J. Mehta (ed), American Geophysical Union, Washington, 148-166.

Leuttich, R.A.J., J.T. Wells and S.-Y. Kim, 1993: In situ variability of large aggregates: Preliminary results on the effects of shear. In: Nearshore and Estuarine Cohesize Sediment Transport Coastal and Estuarine Studies Series, 2. 42, Mehta A.J. (ed.), American Geophysical Union, Washington, 447-466.
McCave, I.N., B. Manighetti, and S.G. Robinson, 1995: Sortable silt and fine sediment size/composition: Parameters for palaeocurrent speed and palaeoceanography. Paleoceanography, 10(3), 593-610.

Milligan, T.G., 1995: An examination of the settling behaviour of a flocculated suspension. Netherlands Journal of Sea Research, 33(2), 163-171.

Milligan, T.G., and P.S. Hill, 1998: A laboratory assessment of the relative importance of turbulence, particle composition, and concentration in limiting maximal floc size. Journal of Sea Research, 39(3/4), 227-241.

Milligan T.G. and D.H. Loring, 1997: The effect of flocculation on bottom sediment size distributions in coastal inlets and its implication for contaminant transport. Water Air and Soil Pollution, 99(1), 33-42.

Ruiz, J. and A. Izquierdo, 1997: A simple model for the break-up of marine aggregates by turbulent shear. Oceanologica Acta, 20(4), 597-606.

Sternberg, R.W., I. Berhane, and A.S. Ogston, in press: Measurement of size and setting velocity of suspended aggreates on the northern California continental shelf. Marine Geology.

Suess, E., 1980: Particulate organic carbon flux in the oceans-surface productivity and oxygen utilization. Nature, 288, 260-263.

Syvitski, J.P.M., K.W. Asprey, and K.W.G. Le Blanc, 1995: In situ characteristics of particles settling within a deep-water estuary. Deep-Sea Research, II 42(1), 223-256.

ten Brinke, W.B.M., 1994: Settling velocities of mud aggregates in the Oosterschelde tidal basin (the Netherlands), determined by a submersible video system. Estuarine Coastal and Shelf Science, 39, 549-564.

van Leussen, W. and J.M. Cornelisse, 1993: The role of large aggregates in estuarine fine-gained sediment dynamics. In: Nearshore and Estuarine Cohesive Sediment Transport, Mehta, A.J., (ed.) American Geophysical Union, Washington D.C., 75-91. 